\title{
Effect of different chemical and seasons on gas exchange parameters, phytohormones, and chlorophyll content in tissue culture plants of Pomegranate (Punica granatum L.) cv. Bhagwa
}

\author{
Hussain, S.F. ${ }^{1}$ 死, Murthy, B.N.S. ${ }^{2}$, Reddy, M.L.N. ${ }^{1}$, Upreti, K.K. ${ }^{2}$, Satisha, ${ }^{2}{ }^{2}$, \\ Laxman, R.H. ${ }^{2}$, Srinivasulu, B. ${ }^{1}$, Reddy, P.S.S. ${ }^{1}$
}

Received: 19.03.2021

Revised: 06.05.2021

Accepted: 25.05.2021

\begin{abstract}
Little is known about rate of photosynthesis, transpiration, stomatal conductance, intrinsic water use efficiency, endogenous phytohormones (Gibberellic acid and Indole acetic acid) concomitant with leaf chlorophyll content during flowering and fruiting stages in pomegranate. As a result, a study was conducted to determine the function of various chemicals, such as Nitrobenzene (NB) at 1.0, 1.5, and $2.0 \mathrm{ml} \mathrm{plant}^{-1}$, Cycocel (CCC) at 500, 1000, and 1500 ppm plant ${ }^{-1}$, Uracil 25 and 50 ppm plant ${ }^{-1}$, CCC1000 ppm + Uracil 25 ppm plant $^{-1}$, CCC 1500 ppm + Uracil 50 ppm plant ${ }^{-1}$, along with control at ICAR - Indian Institute of Horticultural Research (IIHR), Bengaluru, during the flowering and fruit set stages during two seasons, namely ambe bahar (January-February 2016) and hastha bahar (September-October 2016-17). Applications of Uracil $50 \mathrm{ppm}$ plant ${ }^{-1}$, Uracil $25 \mathrm{ppm}^{-1 a n t^{-1}}$ and nitrobenzene $1.5 \mathrm{ml}^{\text {plant }}{ }^{-1}$ at flowering stage resulted in highest rate of photosynthesis $\left(16.48 \mu \mathrm{mol} \mathrm{m}^{-2} \mathrm{~s}^{-1}\right)$, transpiration $\left(7.69 \mathrm{mmol} \mathrm{m} \mathrm{m}^{-2}\right)$ and stomatal conductance $(0.44 \mathrm{~mol}$ $\mathrm{m}^{-2} \mathrm{~s}^{-1}$ ). Foliar spray of Nitrobenzene $1.5 \mathrm{ml} \mathrm{plant}^{-1}$, cycocel $1000 \mathrm{ppm}$ plant ${ }^{-1}+$ Uracil $^{25} \mathrm{ppm}_{\text {plant }}{ }^{-1}$ in conjunction with application of nitrobenzene $1.0 \mathrm{ml} \mathrm{plant}^{-1}$ registered highest rate of photosynthesis $\left(12.55 \mu \mathrm{mol} \mathrm{m}^{-2} \mathrm{~s}^{-1}\right)$, transpiration $(6.19$ mmol m$\left.~^{-2} \mathrm{~s}^{-1}\right)$ and stomatal conductance $\left(0.19 \mathrm{~mol} \mathrm{~m}^{-2} \mathrm{~s}^{-1}\right)$ at fruit set stage. Application of Uracil $50 \mathrm{ppm}^{\mathrm{plant}} \mathrm{resulted}^{-1}$ in higher levels of endogenous IAA content (394.3 $\mathrm{ng} \mathrm{g}^{-1} \mathrm{FW}$ and $\left.885.3 \mathrm{ng} \mathrm{g}^{-1} \mathrm{FW}\right)$, lower levels of GA $\mathrm{G}_{3}$ content (110.7 $\mathrm{ng} \mathrm{g}^{-}$ ${ }^{1} \mathrm{FW}$ and $\left.144.0 \mathrm{ng} \mathrm{g}^{-1} \mathrm{FW}\right)$, and highest total chlorophyll content $\left(3.14 \mathrm{mg} \mathrm{g}^{-1}\right.$ and $\left.1.99 \mathrm{mg} \mathrm{g}^{-1}\right)$ in the leaves at both flowering and fruit set stages. With application of cycocel $1500 \mathrm{ppm}$ plant ${ }^{-1}$ at flowering and fruit set stages, highest photosynthetic rate $\left(17.67 \mu \mathrm{mol} \mathrm{m} \mathrm{m}^{-2} \mathrm{~s}^{-1}\right.$ and $\left.15.71 \mu \mathrm{mol} \mathrm{m} \mathrm{s}^{-2}\right)$, transpiration rate $\left(7.68 \mathrm{mmol} \mathrm{m}^{-2} \mathrm{~s}^{-1}\right.$ and $6.13 \mathrm{mmol} \mathrm{m}^{-2} \mathrm{~s}^{-}$ $\left.{ }^{1}\right)$ and higher levels of endogenous IAA $\left(946.7 \mathrm{ng} \mathrm{g}^{-1} \mathrm{FW}\right.$ and $\left.633.0 \mathrm{ng} \mathrm{g}^{-1} \mathrm{FW}\right)$ were registered respectively. Following application of cycocel $1500 \mathrm{ppm}$ plant $^{-1}$ and $500 \mathrm{ppm}$ plant $^{-1}$ at both flowering and fruit set stages, lower endogenous $\mathrm{GA}_{3}$ (163.3 $\mathrm{ng} \mathrm{g}^{-1} \mathrm{FW}$ and $276.0 \mathrm{ng} \mathrm{g}^{-1} \mathrm{FW}$ ) were observed. At flowering stage, cycocel $1000 \mathrm{ppm} \mathrm{plant}^{-1}+\mathrm{Uracil}^{25} \mathrm{ppm}^{\mathrm{plant}}{ }^{-}$ 1 recorded the highest total chlorophyll content $\left(2.35 \mathrm{mg} \mathrm{g}^{-1}\right)$. During flowering period, cycocel $1500 \mathrm{ppm}^{\mathrm{plant}}{ }^{-1}$ application resulted in the highest stomatal conductance $\left(0.57 \mathrm{~mol} \mathrm{~m}^{-2} \mathrm{~s}^{-1}\right)$. Application of cycocel $1500 \mathrm{ppm}^{-1 a n t^{-1}}+$ Uracil $50 \mathrm{ppm}$ plant $^{-1}$ resulted in the highest stomatal conductance $\left(0.38 \mathrm{~mol} \mathrm{~m}^{-2} \mathrm{~s}^{-1}\right)$ at fruit set stage.
\end{abstract}

Key words: Bhagwa, Physiological Parameters, Plant Growth Regulators, Pomegranate

\section{Introduction}

In arid and semiarid climates, the pomegranate (Punica granatum L.) is a popular fruit crop ( $\mathrm{Pal}$ and Babu, 2015). Because of its adaptability, hardiness, low maintenance cost, and yield, this fruit crop is ideal for tropical and sub-tropical climates (Bankar and Prasad, 1992). It can be grown on marginal and less productive lands because of its adaptability, and it can withstand drought and heat (Jadhav and Sharma, 2007).

\section{Author's Address}

${ }^{1}$ Dr. YSR Horticultural University, College of Horticulture, Anantharajupeta, India.

${ }^{2}$ ICAR - Indian Institute of Horticultural Research, Bengaluru 560089 , India.

E-mail.: fkhanshaik@gmail.com
Photosynthesis is mainly fueled by sunlight, while transpiration is influenced by air temperature and humidity. The drying power of the atmosphere, which is related to wind speed and relative humidity, and the evaporative demand from net radiation absorbed by leaves cause transpiration (Monteith and Unsworth, 1990). Stomata play a role in photosynthesis and transpiration control by allowing $\mathrm{CO}_{2}$ and water vapour to diffuse into and out of the leaf (Jarvis and Morison, 1981). Stomatal aperture control is influenced by state variables (e.g., leaf water potential and intercellular carbon dioxide concentration), interactions between processes (transpiration and photosynthetic rates), 


\section{Hussain et al.}

and environmental factors (in particular, the water vapour concentration difference between the leaf surface and the bulk air) (Jones, 1992).

Photosynthetic rate $\left(P_{N}\right)$, transpiration $(\mathrm{E})$ and stomatal conductance $\left(\mathrm{g}_{\mathrm{s}}\right)$ as well as phytohormones $\left(\mathrm{GA}_{3}\right.$ and IAA) and chlorophyll content, all play a role in determining the plants metabolic activity in terms of its overall growth and development including flower induction. There have been significant studies in the field of various fruit crops such as mango, citrus, apple and sweet cherry etc (Jones, 1992). Arun et al.,, (2017) conducted a trial in Olive to investigate the effects of plant growth regulators on gas exchange, phytohormones and chlorophyll content.

Studies on gas exchange parameters (Photosynthetic rate $\left(P_{N}\right)$, transpiration $(\mathrm{E})$, and stomatal conductance $\left(\mathrm{g}_{\mathrm{s}}\right)$, as well as phytohormones ( $\mathrm{GA}_{3}$ and IAA) and chlorophyll content, were conducted for the first time in pomegranate using chemicals such as Nitrobenzene, Uracil, and Cycocel at various concentrations to investigate the plants metabolic activity.

\section{Materials and Methods}

A field trial was conducted on safe and uniformly grown tissue-cultured plant propagules of pomegranate $\mathrm{cv}$. Bhagwa obtained from M/s Jain Irrigation Pvt. Ltd, Jalgoan, at the ICAR - IIHR, Hesaraghatta, Bengaluru, during the ambe bahar (January - February) and hastha bahar (September - October) seasons of 2016-17. During ambe bahar, the average maximum and minimum temperatures were $33.08^{\circ} \mathrm{C}$ and $20.43^{\circ} \mathrm{C}$, respectively, with relative humidity and rainfall of 75.04 percent and $74.95 \mathrm{~mm}$, and during hastha bahar, the average maximum and minimum temperatures were $26.13^{\circ} \mathrm{C}$ and $18.94^{\circ} \mathrm{C}$, respectively, with relative humidity and rainfall of 59.06 percent and $12.10 \mathrm{~mm}$. All of the plants were stressed for a month by withholding irrigation, and defoliation was accomplished by foliar application of ethrel $2 \mathrm{ml}$ litre (prior to imposition of treatments), followed by twig pruning. The experiment used a randomised block method as the statistical design and consisted of eleven treatments that were repeated three times. The treatments were: $\mathrm{T}_{1}-$ nitrobenzene $1.0 \mathrm{ml} /$ litre, $\mathrm{T}_{2}-$ nitrobenzene $1.5 \mathrm{ml} /$ litre, $\mathrm{T}_{3}$ - nitrobenzene $2.0 \mathrm{ml}$ / litre, $\mathrm{T}_{4}$ - cycocel $500 \mathrm{ppm}, \mathrm{T}_{5}$ - cycocel 1000 ppm, $\mathrm{T}_{6}-$ cycocel $1500 \mathrm{ppm}, \mathrm{T}_{7}-$ uracil $25 \mathrm{ppm}$, $\mathrm{T}_{8}-$ uracil $50 \mathrm{ppm}, \mathrm{T}_{9}$ - cycocel $1000 \mathrm{ppm}+$ uracil $25 \mathrm{ppm}, \mathrm{T}_{10}-$ cycocel $1500 \mathrm{ppm}+$ uracil $50 \mathrm{ppm}$ and $\mathrm{T}_{11}-$ control (water spray). Before and during the study, standard cultural procedures such as desuckering were carried out.

\section{Gibberellins and Indole - 3 - Acetic acid analyses}

The phytohormones like auxin and gibberellic acid were analysed by HPLC procedure of Kelen et al., (2004) with modifications. The HPLC system (Model: Prominence, Shimadzu, Japan) was equipped with photodiode array detector (SPD $\mathrm{M} 20 \mathrm{~A}$ ) and Synergi $4 \mu \mathrm{m}$ fusion $4.6 \mathrm{~mm} \mathrm{RP}-\mathrm{C}_{18}$ column (Phenomenex, USA, $250 \times 4.6 \mathrm{~mm}$ ). The mobile phase consisted of acetonitrile: water $(\mathrm{pH}$ 4.0 , adjusted with $1.0 \mathrm{M}$ o- phosphoric acid) $(30: 70, \mathrm{v} / \mathrm{v})$ at $0.8 \mathrm{ml} / \mathrm{min}$ flow rate.

Five grams of fresh leaf sample was homogenized in liquid nitrogen and phytohormones were extracted in $50 \mathrm{ml}$ of 80 per cent methanol (v/v). The extract was filtered and the residue was extracted again with another $50 \mathrm{ml}$ of 80 per cent methanol. The filtrates were pooled and evaporated in vacuum at $35^{\circ} \mathrm{C}$. The residue was dissolved in 30 $\mathrm{ml}$ distilled water and adjusted to $\mathrm{pH}$ 3.0. The aqueous acidic extract was portioned twice against equal volumes of chilled diethyl ether. The ether phase was separated and dried over anhydrous sodium sulphate. The extract was kept overnight at $4^{0} \mathrm{C}$, filtered and dried in rotary evaporator at $35^{\circ} \mathrm{C}$. The residue was dissolved in $2 \mathrm{ml}$ HPLC grade methanol and filtered through $0.2 \mu \mathrm{m}$ syringe filter for HPLC analysis.

\section{Gas exchange parameters}

Photosynthetic rate $\left(P_{N}\right)$, transpiration rate $(E)$, stomatal conductance $(g s)$, was measured using Portable photosynthesis system (LCpro, ADC BioScientific limited, UK). A minimum of three measurements were taken during 09:30 to 11:30 am from fully mature leaves under ambient light and $\mathrm{CO}_{2}$ level. The mean $\mathrm{CO}_{2}$ concentration during the

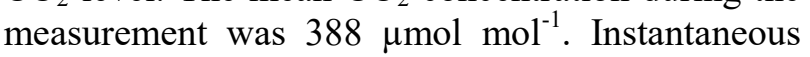
water use efficiency (WUE) was calculated using photosynthetic rate and transpiration rate $\left(P_{N} / E\right)$, intrinsic water use efficiency (WUEi) was calculated from photosynthetic rate and stomatal conductance $\left(P_{N} / g s\right)$. 


\section{Total Chlorophyll content}

The light harvesting pigments were extracted in Dimethyl sulphoxide (DMSO) reagent. During extraction, the samples were protected against light to prevent pigment degradation and estimated using UV-VIS spectrophotometer (T80+ UV/VIS spectrophotometer, PG instrument Ltd, UK) by the method of Lichtenthaler and Buschmann (2001).

\section{Statistical analysis}

The results of the experiment were statistically evaluated using normal procedures (Panse and Sukhatme, 1978). The F value was used to measure statistical significance at a $5 \%$ level of significance. For the effects that were important, a critical difference at 0.05 levels was calculated.

\section{Results and Discussion}

At flowering and fruit set stages of ambe bahar, data on photosynthetic rate was collected (Table 1). At flowering, growth regulator treatments significantly altered the $P_{N}$, which was especially high $\left(16.48 \mathrm{~mol} \mathrm{~m}^{-2} \mathrm{~s}^{-1}\right)$ in plants treated with Uracil@50 ppm litre $^{-1}$ plant $^{-1}$. At the fruit set stage, plants treated with nitrobenzene $1.5 \mathrm{ml} /$ litre had a high $P_{N}\left(12.55 \mathrm{~mol} \mathrm{~m}^{-2} \mathrm{~s}^{-1}\right)$. In the case of hastha bahar, plants treated with cycocel @ 1500 ppm plant ${ }^{-1}$ had the highest $P_{N}\left(17.67 \mu \mathrm{mol} \mathrm{m}^{-2} \mathrm{~s}^{-1}\right.$ and $\left.15.71 \mu \mathrm{mol} \mathrm{m} \mathrm{m}^{-2} \mathrm{~s}^{-1}\right)$ during flowering and fruit set stages. High chlorophyll content can contribute to an increased net photosynthetic rate during the flowering stage. The finding is supported by Caemmerer and Farquhar (1981). Source leaves with high sinks, such as reproductive organs, have lower carbohydrate levels (Aczon - Bieto, 1983; Lenz and Kuntzel, 1974). According to researchers, repression of photosynthetic genes occurs during the fruit set stage as a result of a lack of sink (Moore et al., 1999). Sink limitation may cause a long-term decrease in photosynthetic ability by repressing the expression of photosynthetic genes, especially the gene encoding the Rubisco small subunit protein, according to numerous observations of acclimation to elevated $\mathrm{CO}_{2}$ concentrations (Rogers et al., 2004). If the hexoseto-sucrose ratio indicates sink limitation (Moore et al., 1999), the fact that the hexose-to-sucrose ratio in leaves close to fruits is more than 4-fold higher than in standard leaves supports the idea that sink limitation reduces photosynthetic potential in leaves close to fruits. Flowers have a low carbon requirement, according to Lewis et al. (2002) and sink activity decreases as flowering begins. We believe that the soluble sugars needed for flowering in Persea americana L. (Liu et al., 1999) were obtained from starch conversion in the stems, and that the relatively high sucrose concentration in the phloem prevented phloem loading from the leaves. Flowering and low photosynthetic rates in leaves near inflorescences are linked to carbohydrate concentrations in stems, if our hypothesis is right. Alternatively, since ABA levels in mango leaves rise near inflorescences and ABA has been shown to suppress photosynthetic genes in a variety of plant species, the observed decrease in photosynthetic potential in leaves near inflorescences may be due to ABA accumulation (Rook et al., 2006). Plants sprayed with uracil 25 ppm had the highest transpiration rate during the flowering stage of ambe bahar $\left(7.72 \mathrm{mmol} \mathrm{m}^{-2} \mathrm{~s}^{-1}\right)$ When it came to fruit set, the application of Cycocel $1000 \mathrm{ppm}+$ uracil $25 \mathrm{ppm}$ resulted in the highest transpiration rate $\left(6.19 \mathrm{mmol} \mathrm{m} \mathrm{m}^{-2} \mathrm{~s}^{-1}\right)$. The highest transpiration rates $\left(7.68 \mathrm{mmol} \mathrm{m} \mathrm{m}^{-2} \mathrm{~s}^{-1}\right.$ and $6.13 \mathrm{mmol} \mathrm{m}^{-2} \mathrm{~s}^{-1}$ ) were reported in hastha bahar plants following application of Cycocel $1500 \mathrm{ppm}$ at both flowering and fruit set levels. Increased stomatal size (length and breadth) and less ABA accumulation in the leaves may explain cycocel's beneficial effect on transpiration rate. On the other hand, Blanco et al., (1997) discovered that cycocel decreased stomatal size in terms of length and width, possibly lowering the transpiration rate in peach leaves. Due to application of various chemicals, the E gradually decreased at fruit set level. The decrease in $\mathrm{E}$ is most likely due to accumulation of ABA in the leaves. These findings are consistent with those of Arun et al. (2016) who reported that the application of cycocel to olive $\mathrm{cv}$. Pendulino caused a steady decrease in transpiration rate. Plants treated with nitrobenzene $1.5 \mathrm{ml}$ and $1.0 \mathrm{ml}$ had the highest stomatal conductance during both flowering and fruit set stages of ambe bahar ( $0.44 \mathrm{~mol} \mathrm{~m}^{-2} \mathrm{~s}^{-1}$ and $0.19 \mathrm{~mol} \mathrm{~m}^{-2} \mathrm{~s}^{-1}$ respectively). Plants treated with cycocel $1500 \mathrm{ppm}$ or cycocel $1500 \mathrm{ppm}+$ uracil $50 \mathrm{ppm}$ had the highest stomatal conductance during the flowering and fruit set stages of hastha bahar $\left(0.57 \mathrm{~mol} \mathrm{~m}^{-2} \mathrm{~s}^{-1}\right.$ and 0.38 $\left.\mathrm{mol} \mathrm{m} \mathrm{s}^{-1}\right)$. 
Table 1: During the flowering and fruit set stages of the pomegranate cv. Bhagwa, gas exchange parameters were affected by various chemicals (data reflect mean $\mathrm{SE} ; \mathrm{n}=4$ )

\begin{tabular}{|c|c|c|c|c|c|c|c|c|c|c|c|c|}
\hline \multirow[b]{3}{*}{ Treatments } & \multicolumn{6}{|c|}{ Ambebahar } & \multicolumn{6}{|c|}{ Hasthabahar } \\
\hline & \multicolumn{3}{|c|}{ Flowering stage } & \multicolumn{3}{|c|}{ Fruit set stage } & \multicolumn{3}{|c|}{ Flowering stage } & \multicolumn{3}{|c|}{ Fruit set stage } \\
\hline & 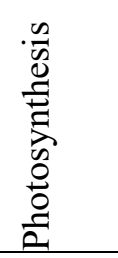 & 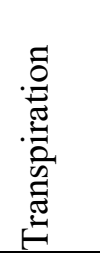 & 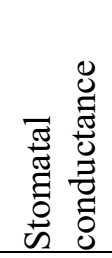 & 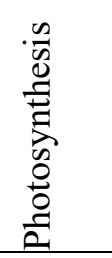 & 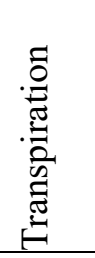 & 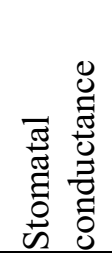 & 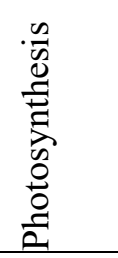 & 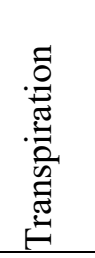 & 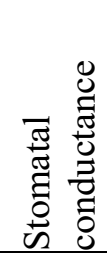 & 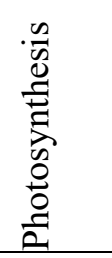 & 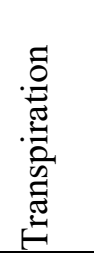 & 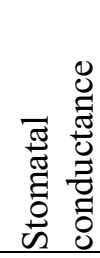 \\
\hline $\begin{array}{l}\mathrm{T}_{1}: \text { nitrobenzene } \\
1.0 \mathrm{~mL} / \text { plant }\end{array}$ & 15.22 & 3.49 & 0.43 & 9.80 & 4.45 & 0.19 & 10.34 & 3.79 & 0.27 & 9.51 & 3.08 & 0.14 \\
\hline $\begin{array}{l}\mathrm{T}_{2}: \text { nitrobenzene } \\
1.5 \mathrm{~mL} / \text { plant }\end{array}$ & 13.41 & 4.92 & 0.44 & 12.55 & 4.83 & 0.14 & 14.49 & 4.30 & 0.29 & 13.40 & 2.98 & 0.14 \\
\hline $\begin{array}{l}\mathrm{T}_{3}: \text { nitrobenzene } 2.0 \\
\mathrm{~mL} / \text { plant }\end{array}$ & 11.63 & 5.07 & 0.38 & 9.48 & 4.94 & 0.16 & 13.78 & 4.85 & 0.38 & 12.86 & 4.09 & 0.16 \\
\hline $\begin{array}{l}\mathrm{T}_{4}: \text { Cycocel } 500 \\
\text { ppm }\end{array}$ & 14.65 & 4.21 & 0.23 & 10.63 & 5.32 & 0.14 & 14.88 & 6.48 & 0.41 & 13.62 & 4.93 & 0.17 \\
\hline $\begin{array}{l}\mathrm{T}_{5}: \text { Cycocel1000 } \\
\mathrm{ppm}\end{array}$ & 14.12 & 5.56 & 0.31 & 11.71 & 5.73 & 0.16 & 16.03 & 7.14 & 0.48 & 14.70 & 6.08 & 0.17 \\
\hline $\begin{array}{l}\mathrm{T}_{6}: \text { Cycocel } 1500 \\
\text { ppm }\end{array}$ & 13.28 & 6.53 & 0.31 & 10.87 & 5.08 & 0.13 & 17.67 & 7.68 & 0.57 & 15.71 & 6.13 & 0.29 \\
\hline $\mathrm{T}_{7}:$ uracil $25 \mathrm{ppm}$ & 15.22 & 7.72 & 0.31 & 10.67 & 3.44 & 0.14 & 11.82 & 4.96 & 0.34 & 10.81 & 3.46 & 0.16 \\
\hline $\mathrm{T}_{8}:$ uracil $50 \mathrm{ppm}$ & 16.48 & 7.03 & 0.26 & 9.55 & 3.85 & 0.15 & 12.87 & 5.31 & 0.27 & 11.64 & 3.72 & 0.19 \\
\hline $\mathrm{T}_{9}: \mathrm{T} 5+\mathrm{T} 7$ & 11.53 & 7.03 & 0.21 & 11.88 & 6.19 & 0.18 & 11.44 & 5.86 & 0.25 & 10.68 & 3.56 & 0.19 \\
\hline $\mathrm{T}_{10}: \mathrm{T} 6+\mathrm{T} 8$ & 13.84 & 7.69 & 0.24 & 10.26 & 4.58 & 0.13 & 14.51 & 5.28 & 0.30 & 13.93 & 2.56 & 0.38 \\
\hline $\mathrm{T}_{11}:$ Control & 10.47 & 2.37 & 0.09 & 9.00 & 3.48 & 0.13 & 9.48 & 3.72 & 0.25 & 8.65 & 2.29 & 0.18 \\
\hline C.D. at $5 \%$ & 4.21 & 1.74 & 0.16 & 3.24 & 1.89 & 0.07 & 1.43 & 1.22 & 0.10 & 1.40 & 0.80 & N.S. \\
\hline S. Em $( \pm)$ & 1.42 & 0.59 & 0.05 & 1.09 & 0.64 & 0.02 & 0.48 & 0.41 & 0.03 & 0.47 & 0.27 & 0.07 \\
\hline
\end{tabular}

N.S - Non Significant 
Effect of different chemical and seasons on gas exchange parameters

Table 2: Intrinsic water use efficiency in Pomegranate cv. Bhagwa as influenced by different chemicals (data represent mean $\pm S E ; n=4$ )

\begin{tabular}{|l|l|l|l|l|}
\hline \multirow{2}{*}{ Treatments } & \multicolumn{2}{|l|}{ Ambebahar } & \multicolumn{2}{l|}{ Hasthabahar } \\
\cline { 2 - 5 } & $\begin{array}{l}\text { Flowering } \\
\text { stage }\end{array}$ & $\begin{array}{l}\text { Fruit set } \\
\text { stage }\end{array}$ & $\begin{array}{l}\text { Flowering } \\
\text { stage }\end{array}$ & $\begin{array}{l}\text { Fruit set } \\
\text { stage }\end{array}$ \\
\hline $\mathrm{T}_{1}:$ nitrobenzene $1.0 \mathrm{~mL} /$ plant & 4.34 & 2.45 & 2.16 & 2.18 \\
\hline $\mathrm{T}_{2}:$ nitrobenzene $1.5 \mathrm{~mL} /$ plant & 2.80 & 2.62 & 2.22 & 2.47 \\
\hline $\mathrm{T}_{3}:$ nitrobenzene2 $.0 \mathrm{~mL} /$ plant & 2.30 & 1.88 & 2.39 & 2.60 \\
\hline $\mathrm{T}_{4}:$ Cycocel $500 \mathrm{ppm}$ & 3.81 & 2.00 & 2.66 & 3.40 \\
\hline $\mathrm{T}_{5}:$ Cycocel1000 ppm & 2.54 & 2.04 & 2.93 & 3.74 \\
\hline $\mathrm{T}_{6}:$ Cycocel $1500 \mathrm{ppm}$ & 2.06 & 2.14 & 3.12 & 4.28 \\
\hline $\mathrm{T}_{7}:$ uracil $25 \mathrm{ppm}$ & 1.98 & 3.09 & 2.50 & 2.95 \\
\hline $\mathrm{T}_{8}:$ uracil $50 \mathrm{ppm}$ & 2.40 & 2.53 & 2.62 & 3.06 \\
\hline $\mathrm{T}_{9}: \mathrm{T} 5+\mathrm{T} 7$ & 4.52 & 1.93 & 2.64 & 3.11 \\
\hline $\mathrm{T}_{10}: \mathrm{T} 6+\mathrm{T} 8$ & 1.79 & 2.29 & 2.62 & 3.08 \\
\hline $\mathrm{T}_{11}:$ Control & 1.65 & 2.66 & 2.13 & 2.14 \\
\hline C.D. at $5 \%$ & 1.13 & $\mathrm{~N} . \mathrm{S}$. & $\mathrm{N} . \mathrm{S}$. & $\mathrm{N} . \mathrm{S}$. \\
\hline $\mathrm{S}$. Em $( \pm)$ & 0.38 & 0.27 & 0.22 & 0.42 \\
\hline
\end{tabular}

When compared to control plants, cycocel treated plants had higher stomatal conductance $\left(\mathrm{g}_{\mathrm{s}}\right)$ compared to control plants (no chemical treatment). Endogenous IAA levels are known to control stomatal conductance (opening and closure of stomata). Plants treated with cycocel at various concentrations had optimum levels of endogenous IAA in their leaves, which could have improved stomatal conductance $\left(\mathrm{g}_{\mathrm{s}}\right), \mathrm{H}+$ extrusion through the plasma membrane causes stomatal opening, which is catalysed by the H+-ATPase, which is activated by red or blue light and possibly auxins. These findings are consistent with Schroeder et al. (2001). According to Monselise and Lenz (1980), gas exchange parameters decreased at the fruit set stage compared to the flowering stage, which may be attributed to a higher demand for photosynthates at the start of flowering. Leaves adjacent to growing flowers have a higher photosynthesis rate than leaves adjacent to vegetative shoots, according to Masarovicova and Novara (1994). Plants treated with a solution of $1000 \mathrm{ppm}$ cycocel $+25 \mathrm{ppm}$ uracil at flowering stage had the highest intrinsic water use efficiency (4.52) during ambe bahar. However, no major differences in intrinsic water use efficiency were found during hasthabahar of flowering and fruit set stages. The application of cycocel improved water use efficiency (WUE) at both flowering and fruiting stages (Table 2).

The higher WUE is due to a higher increase in photosynthetic rate over transpiration rate, which is needed for flowering to start. Higher WUE helps plants in achieving better flowering because water availability is crucial for the onset and growth of flowering. Reduced stomatal aperture and shoot growth result in less surface area for transpiration, more roots for water absorption, and structural improvements in leaves that provide water loss barriers, all of which strengthen plant water connections (Soumya et al., 2017). During flowering and fruit set stages of ambe bahar, lower endogenous levels of $\mathrm{GA}_{3}\left(110.66 \mathrm{ng} \mathrm{g}^{-1} \mathrm{FW}\right.$ and 
Hussain et al.

Table 3: Phytohormone content (ng $\left.\mathrm{g}^{-1} \mathrm{FW}\right)$ in pomegranate $\mathrm{cv}$. Bhagwa at flowering and fruit set stages

\begin{tabular}{|c|c|c|c|c|c|c|c|c|}
\hline \multirow{3}{*}{ Treatments } & \multicolumn{4}{|c|}{ Ambebahar } & \multicolumn{4}{|c|}{ Hasthabahar } \\
\hline & \multicolumn{2}{|c|}{ Flowering stage } & \multicolumn{2}{|c|}{ Fruit set stage } & \multicolumn{2}{|c|}{ Flowering stage } & \multicolumn{2}{|c|}{ Fruit set stage } \\
\hline & $\mathrm{GA}_{3}$ & IAA & $\mathrm{GA}_{3}$ & IAA & $\mathrm{GA}_{3}$ & IAA & $\mathrm{GA}_{3}$ & IAA \\
\hline $\begin{array}{l}\mathrm{T}_{1}: \text { nitrobenzene } 1.0 \mathrm{~mL} \\
\text { / plant }\end{array}$ & 399.33 & 382.66 & 211.00 & 874.33 & 287.00 & 441.66 & 359.00 & 348.66 \\
\hline $\begin{array}{l}\mathrm{T}_{2}: \text { nitrobenzene } 1.5 \mathrm{~mL} \\
\text { / plant }\end{array}$ & 402.33 & 346.33 & 277.00 & 756.00 & 261.33 & 501.00 & 349.33 & 359.66 \\
\hline $\begin{array}{l}\mathrm{T}_{3}: \text { nitrobenzene } 2.0 \mathrm{~mL} / \\
\text { plant }\end{array}$ & 122.33 & 372.33 & 218.33 & 850.66 & 235.66 & 774.33 & 311.00 & 389.66 \\
\hline $\mathrm{T}_{4}:$ Cycocel $500 \mathrm{ppm}$ & 121.00 & 211.00 & 382.66 & 756.00 & 186.33 & 879.33 & 276.00 & 458.00 \\
\hline $\mathrm{T}_{5}:$ Cycocel1000 ppm & 190.66 & 182.66 & 346.33 & 480.00 & 174.33 & 907.66 & 325.66 & 480.00 \\
\hline $\mathrm{T}_{6}:$ Cycocel $1500 \mathrm{ppm}$ & 297.66 & 218.33 & 389.33 & 392.33 & 163.33 & 946.66 & 307.66 & 633.00 \\
\hline $\mathrm{T}_{7}:$ uracil $25 \mathrm{ppm}$ & 119.00 & 389.33 & 182.66 & 878.00 & 175.33 & 697.00 & 294.33 & 390.66 \\
\hline $\mathrm{T}_{8}:$ uracil $50 \mathrm{ppm}$ & 110.66 & 394.33 & 144.00 & 885.33 & 185.00 & 625.66 & 298.00 & 323.33 \\
\hline $\mathrm{T}_{9}: \mathrm{T} 5+\mathrm{T} 7$ & 204.66 & 291.33 & 291.33 & 204.00 & 202.00 & 641.33 & 288.00 & 363.00 \\
\hline $\mathrm{T}_{10}: \mathrm{T} 6+\mathrm{T} 8$ & 402.33 & 277.00 & 372.33 & 217.00 & 237.00 & 654.66 & 305.00 & 368.00 \\
\hline $\mathrm{T}_{11}$ : Control & 918.00 & 144.00 & 394.33 & 111.00 & 283.33 & 367.66 & 383.66 & 318.00 \\
\hline C.D. at $5 \%$ & 284.61 & 37.36 & 37.36 & 326.00 & 26.25 & 54.71 & 44.40 & 46.69 \\
\hline S. Em $( \pm)$ & 95.80 & 12.57 & 12.57 & 109.73 & 8.83 & 18.41 & 14.94 & 15.71 \\
\hline
\end{tabular}

$114.00 \mathrm{ng} \mathrm{g}^{-1} \mathrm{FW}$ ) were observed in the leaves of Table 4 shows that during the flowering stage of the crop when Uracil 50 ppm plant ${ }^{-1}$ was applied, ambe bahar, plants sprayed with Uracil @ 50 ppm while higher levels of endogenous IAA (394.22 ng $\mathrm{g}^{-1} \mathrm{FW}$ and $885.33 \mathrm{ng} \mathrm{g}^{-1} \mathrm{FW}$ ) were observed with same chemical. At both flowering and fruit set stages of hastha bahar, application of cycocel @ $1500 \mathrm{ppm}^{\text {plant }}{ }^{-1}$ and $500 \mathrm{ppm}$ plant $^{-1}$ decreased the endogenous $\mathrm{GA}_{3}$ levels $\left(163.33 \mathrm{ng} \mathrm{g}^{-1} \mathrm{FW}\right.$ and $\left.276.00 \mathrm{ng} \mathrm{g}^{-1} \mathrm{FW}\right)$ in the leaves, while application of cycocel@1500 ppm plant ${ }^{-1}$ increased the endogenous levels (946.66 $\mathrm{ng} \mathrm{g}^{-1} \mathrm{FW}$ and 633.00 ng $\mathrm{g}^{-1} \mathrm{FW}$ ) (Table 3). Cycocel is known to suppress endogenous gibberellin levels at both flowering and fruiting stages, which may be due to its role in inhibiting the conversion of geranyl geranyl pyrophosphate to ent - kaurene, lowering endogenous gibberellins in this sample. Arun et al., (2016) identified similar research in the Pendulino variety of Olive. ambe bahar, plants sprayed with Uracil@50 ppm
had higher chlorophyll a content $(1.34 \mathrm{mg}$ g-1) and total chlorophyll content $(3.14 \mathrm{mg} \mathrm{g}-1)$. When nitrobenzene was applied as a spray@1.5 ml litre ${ }^{-1}$ plant $^{-1}$, the plants had higher chlorophyll a $(0.72 \mathrm{mg}$ $\left.\mathrm{g}^{-1}\right)$ and chlorophyll b (1.15 $\left.\mathrm{mg} \mathrm{g}^{-1}\right)$ content. During the flowering stage of hastha bahar, plants treated with cycocel at 500 ppm plant $^{-1}$ had a high chlorophyll a material $\left(1.47 \mathrm{mg} \mathrm{g}^{-1}\right)$. At fruit set stage, however, cycocel @ 1500 ppm plant $^{-1}$ application resulted in high chlorophyll b $(1.24 \mathrm{mg}$ $\left.\mathrm{g}^{-1}\right)$ and total chlorophyll content $\left(2.35 \mathrm{mg} \mathrm{g}^{-1}\right)$.

Chlorophyll biosynthesis is stimulated by ancymidol via increased chloroplast differentiation and stimulating photosynthetic enzymes, which may explain why total chlorophyll content improved following application of cycocel at both flowering and fruiting levels (Chung et al., 1999). 
Effect of different chemical and seasons on gas exchange parameters

Table 4: Effects of different chemicals on total chlorophyll content $\left(\mathrm{mg} \mathrm{g}^{-1}\right)$ in pomegranate cv. Bhagwa

\begin{tabular}{|c|c|c|c|c|c|c|c|c|c|c|c|c|}
\hline \multirow{3}{*}{ Treatments } & \multicolumn{6}{|c|}{ Ambe bahar } & \multicolumn{6}{|c|}{ Hastha bahar } \\
\hline & \multicolumn{3}{|c|}{ Flowering stage } & \multicolumn{3}{|c|}{ Fruit set stage } & \multicolumn{3}{|c|}{ Flowering stage } & \multicolumn{3}{|c|}{ Fruit set stage } \\
\hline & Chl a & Chl b & $\begin{array}{l}\text { Total } \\
\text { Chl }\end{array}$ & Chl a & Chl b & $\begin{array}{l}\text { Total } \\
\text { Chl }\end{array}$ & Chl a & Chl b & $\begin{array}{l}\text { Total } \\
\text { Chl }\end{array}$ & Chl a & Chl b & $\begin{array}{l}\text { Total } \\
\text { Chl }\end{array}$ \\
\hline $\begin{array}{l}\mathrm{T}_{1} \text { : nitrobenzene } 1.0 \mathrm{~mL} \\
\text { / plant }\end{array}$ & 1.09 & 1.67 & 2.76 & 0.12 & 0.74 & 1.98 & 1.09 & 0.55 & 1.65 & 0.92 & 0.69 & 1.60 \\
\hline $\begin{array}{l}\mathrm{T}_{2}: \text { nitrobenzene } 1.5 \mathrm{~mL} \\
\text { / plant }\end{array}$ & 1.11 & 1.63 & 2.74 & 0.72 & 1.15 & 1.87 & 1.11 & 0.57 & 1.68 & 0.91 & 0.77 & 1.68 \\
\hline $\begin{array}{l}\mathrm{T}_{3}: \text { nitrobenzene } 2.0 \mathrm{~mL} / \\
\text { plant }\end{array}$ & 1.03 & 1.71 & 2.75 & 0.19 & 0.73 & 1.91 & 1.34 & 0.73 & 2.07 & 1.09 & 0.82 & 1.91 \\
\hline $\mathrm{T}_{4}:$ Cycocel $500 \mathrm{ppm}$ & 0.91 & 1.37 & 2.29 & 0.65 & 0.65 & 1.67 & 1.03 & 0.99 & 2.02 & 1.34 & 0.73 & 2.07 \\
\hline $\mathrm{T}_{5}:$ Cycocel1000 ppm & 1.09 & 1.50 & 2.59 & 0.19 & 0.65 & 1.75 & 1.06 & 1.00 & 2.07 & 1.11 & 0.99 & 2.10 \\
\hline $\mathrm{T}_{6}:$ Cycocel $1500 \mathrm{ppm}$ & 0.87 & 1.26 & 2.13 & 0.64 & 1.01 & 1.65 & 1.37 & 0.90 & 2.27 & 1.10 & 1.24 & 2.35 \\
\hline $\mathrm{T}_{7}:$ uracil $25 \mathrm{ppm}$ & 1.10 & 1.85 & 2.96 & 0.13 & 0.74 & 1.98 & 1.10 & 0.52 & 1.62 & 1.10 & 0.52 & 1.62 \\
\hline $\mathrm{T}_{8}:$ uracil $50 \mathrm{ppm}$ & 1.34 & 1.80 & 3.14 & 0.19 & 0.76 & 1.99 & 1.11 & 0.99 & 2.10 & 1.11 & 0.57 & 1.68 \\
\hline $\mathrm{T}_{9}: \mathrm{T} 5+\mathrm{T} 7$ & 1.10 & 1.55 & 2.66 & 0.22 & 0.69 & 1.79 & 1.10 & 1.24 & 2.35 & 1.09 & 0.55 & 1.65 \\
\hline $\mathrm{T}_{10}: \mathrm{T} 6+\mathrm{T} 8$ & 1.10 & 1.47 & 2.58 & 0.20 & 0.66 & 1.74 & 0.92 & 0.69 & 1.60 & 1.03 & 0.99 & 2.02 \\
\hline $\mathrm{T}_{11}$ : Control & 0.71 & 1.18 & 1.89 & 0.62 & 1.01 & 1.64 & 0.68 & 0.69 & 1.37 & 0.68 & 0.69 & 1.37 \\
\hline C.D. at $5 \%$ & 0.23 & N.S. & 0.68 & 0.09 & 0.15 & 0.24 & 0.22 & N.S. & 0.57 & 0.23 & N.S. & N.S. \\
\hline S. Em $( \pm)$ & 0.07 & 0.18 & 0.23 & 0.03 & 0.05 & 0.08 & 0.07 & 0.15 & 0.19 & 0.07 & 0.17 & 0.21 \\
\hline
\end{tabular}

- $\quad$ N.S. - Non significant

- $\quad$ Chl - Chlorophyll

- Chl a-Chlorophyll a

- $\quad \mathrm{Chl} \mathrm{b}$ - Chlorophyll b 


\section{Hussain et al.}

The increase in total chlorophyll content may also be attributed to cycocel blocking gibberellin production, causing intermediate compounds to be shunted to the production of phytol, which is an integral part of chlorophyll (Srilatha et al., 2014).

\section{Conclusions}

Finally, application of Uracil $50 \mathrm{ppm}+$ Cycocel 1500 ppm plant ${ }^{-1}$, Cycocel 1500 ppm plant $^{-1}$, and

\section{References}

Azcon-Bieto, J. 1983. Inhibition of photosynthesis by carbohydrates in wheat leaves. Plant Physiology, 73: 681686.

Arun Kumar, Sharma, N. and Gopal Singh. 2016. Effect of paclobutrazol and cycocel on growth, flowering and physiological characteristics of olive cv. Pendulino. Plant Archives, 16: 110-114.

Arun Kumar, Singh, R.P. and Sharma, N. 2017. Influence of paclobutrazol and cycocel on growth, fruitfulness and physiological characteristics of olive (Olea europea L.). Plant Archives, 17: 83-88.

Bankar, G.J. and Prasad, R.N. 1992. Performance of important pomegranate cultivars in arid region. Annals of Arid Zone. 31(3): 181-183.

Blanco, A, Lowery, M, Montero, M, Mora-urpi, J. and Rojas pejibaye, M. El 1997. su uso en la alimentación humana. San Jose: Instituto Costarricense de Investigación y Enseñanza en Nutrición y Salud. 1-7.

Caemmerer Von S. and Farquhar, G.D. 1981. Some relationships between the biochemistry of photosynthesis and the gas exchange of leaves. Planta. 153: 376-387.

Chung, J., Park, K. Y., Kim, Y. H., Jee, S. and Jaechul, K. 1999. Effect of growth retardants on the growth of Bletellastriata In Vitro. Journal of Korean Society of Horticultural Sciences. 40: 485-488.

Jadhav, V.T. and Sharma, J. 2007. Pomegranate cultivation is promising. Indian Horticulture. 30-31.

Jain, M.C. and Dashora, L.K. 2007. Growth, flowering, fruiting and yield of guava (Psidium guajava L.) cv. SARDAR as influenced by various plant growth regulators. International Journal of Agricultural Sciences. 3(1): 4-7.

Jarvis, P.G. and Morison, J.I.L. 1981. The control of transpiration and photosynthesis by the stomata. In Stomatal Physiology. Eds. P.G. Jarvis and T.A. Mansfield. Cambridge University Press, Cambridge, U.K., PP $247-$ 279.
Nitrobenzene $1.5 \mathrm{ml}$ improved photosynthesis, transpiration, stomatal conductance, and intrinsic water use efficiency besides raising the levels of endogenous IAA by lowering the levels of endogenous $\mathrm{GA}_{3}$ in leaves with application of cycocel while also increasing the total chlorophyll content during the flowering and fruit set stages of ambe bahar and hastha bahar.

Jones, H.G. 1992. Stomatal control of photosynthesis and transpiration. Journal of experimental Botany. 49: 387398.

Kelen, M., Demiralay, E.C, Sen, S. and Ozkan, G. 2004. Separation of abscisic acid, indole-3-acetic acid, gibberellic acid in $99 \mathrm{R}$ (Vitis berlandieri $\times$ Vitis 17 rupestris) and rose oil (Rosa damascena Mill.) by Reversed Phase Liquid Chromatography. Turkish Journal of Chemistry. 28: 603610.

Lenz, F. and Kuntzel, U. 1974. Carbohydrate content of citrus as affected by fruit load. - Gartenbauwissenschaft. 39: 99101.

Lewis, J.D., Wang, X.Z., Griffin, K.L. and Tissue, D.T. 2002. Effects of age and ontogent on photosynthetic responses of a determinate annual plant to elevated $\mathrm{CO}_{2}$ concentrations. Plant Cell Environment. 25: 359-368.

Lichtenthaler, H.K. and Buschmann, C. 2001. Chlorophylls and Carotenoids. Pigments of photosynthetic biomembranes. Journal of enzyme and chemistry. 148:350382.

Liu, X., Robinson, P.W., Madore, M.A., Witney, G.W. and Arpaia, M.L. 1999. 'Hass' avocado carbohydrate fluctuations. I. Growth and phenology. Journal of American Society of Horticultural Sciences. 124: 671675.

Masarovicova, E., and Novara, J. 1994. Influence of fruit load on $\mathrm{CO}_{2}$ exchange, water uptake and biomass of apple trees. Gartenbauwissenchaft. 59: 132-138.

Monselise, S.P. and Lenz, F. 1980. Effect of fruit load on stomatal resistance, specific leaf weight, and water content of apple leaves. Gartenbauwissenschaft. 45: 188-191.

Monteith, J.L. and Unsworth, M.H. 1990. Principles of environmental physics, $2^{\text {nd }}$ Edn. Edward Arnold, London, $291 \mathrm{p}$.

Moore, B.D., Cheng, S.H., Sims, D. and Steemann, J.R. 1999. The biochemical and molecular basis for photosynthetic acclimation to elevated atmospheric $\mathrm{CO}_{2}$. Plant Cell Environment. 22: 567-582. 
Pal, R.K. and Babu, K.D. 2014. Postharvest management and total utilization of pomegranate (Punica granatum L.). (In) Souvenir - National seminar - cum - exhibition on Pomegranate for nutrition, livelihood security and entrepreneurship development, 05-07 December 2014, ICAR - NRC on Pomegranate, Solapur, pp $252-261$.

Ramteke, S.D. and Somkumar, R.G. 2005. Effect of cycocel sprays on growth and yield of Tas - A - Ganesh grapes grafted on Dogridge Rootstock. Karnataka Journal of Agricultural Sciences. 18(1): 18-20.

Rogers, A., Allen, D.J., and Davey. 2004. Leaf photosynthesis and carbohydrate dynamics of soybeans grown through out their life cycle under free air carbon dioxide enrinchment. Plant Cell Environment. 27: 449-458.

Rook, F., Hadingham, S.A., Li, Y. and Bevan, M.W. 2006. Sugar and ABA response pathways and the control of gene expression. Plant Cell Environment. 29: 426-434.

Schroeder, J., Kwak, J. M. and Allen, G.J. 2001. Guard cell Abscicic acid signaling and engineering drought hardiness in plants. Nature. 410: 327.330.
Sevda, S.B. and Rodrigues, L. 2011. The making of pomegranate wine using yeast immobilized sodium alginate. African Journal of Food Science. 5: 299-304.

Sharma, K.K. and Nav Prem, S. 2002. Effect of mechanical deblossoming on fruit development in pomegranate (Punica granatum L.). Journal of Research Punjab Agricultural University. 39: $368-372$.

Srilatha, V., Reddy, Y.T.N., Upreti, K. K. and Jagannath, S. 2015. Pruning and paclobutrazol induced vigour, flowering and hormonal changes in mango (Mangifera indica L.). The Bioscan. 10: 161-166.

Soumya, P.R., Pramod kumar and Madan Pal. 2017. Paclobutrazol : a novel plant growth regulator and multistress ameliorant. Indian Journal of Plant Physiology. 22(3): 267-278.

Terashima Ichiro and John Evans, R. 1988. Effects of light and nitrogen nutrition on the organisation of the photosynthetic approach in Spinach. Plant and Cell Physiology. 29: 143155. 